Short Paper

\title{
The Effect of Photoperiod on Growth and Egg Production of the Sea Hare Aplysia dactylomela Rang
}

\author{
Stefanos Palatzidis, ${ }^{* 1}$ Shigehisa Yamasaki, ${ }^{* 1}$ and Takehiko Imai ${ }^{* 2}$ \\ *1Laboratory of Aquaculture Physiology, Kagoshima University, \\ Shimo-arata, Kagoshima 890, Japan \\ ${ }^{*}$ Laboratory of Fishing Gears, Kagoshima University, Shimo-arata, \\ Kagoshima 890, Japan
}

(Received July 17, 1995)

Key words: Aplysia, dark regime, light conditions, Ulva, sea hare

The opisthobranch mollusc Aplysia is utilized as a model preparation for neurophysiological and neurobehavioral studies, because of its well identified cells with known interconnections and behavioral functions. ${ }^{1}$ Certain chemicals in its body and egg mass have antimicrobial and antileukemial activities. ${ }^{2,3)}$ The sea hare itself is edible and its egg mass is directly utilized as food in some parts of Asia, such as the Philippines (E.A.T. Floreto: Kagoshima Univ., pers. comm., 1995). Therefore the culture of the sea hare using macroalgae that are byproducts of aquacultural biofilters ${ }^{4)}$ or collected from nature due to their abundance and apparently of low economic value, presents new exciting possibilities in the utilization of both this gastropod and macroalgae. This study describes the effects of photoperiod on culture of Aplysia dactylomela, a cosmopolitan species of sea hare, ${ }^{1)}$ using the common green seaweed: Ulva pertusa. This macroalgae is the most frequently used seaweed in biofilters and their overabundance in the wild fouls fish cages and plays a significant role in the pollution of coastal waters and shrimp ponds when it decomposes. ${ }^{5,6)}$ Aplysia prefers green seaweeds over red or brown seaweed. ${ }^{7)}$ Adults (211.2 $\pm 6.5 \mathrm{~g}$ wet weight) of $A$. dactylomela, which had been acclimated for a week in indoor aquaria at ambient seawater temperature and under natural photoperiod, using $U$. pertusa as food, were stocked in six $45 l$ aquaria and divided into two groups. For group one, aquaria were covered with an opaque material to minimize light influence, and for the second group, the uncovered aquaria were placed near a window facing south and subjected to the natural light conditions of the Kagoshima area from the 28th of March until the 26th of April, 1994. The average duration of the dark period was $11.2 \pm 0.3 \mathrm{~h},{ }^{8}$ and the average light intensity at water surface of the aquaria was $6.06 \pm 3.10 \mathrm{~mol} / \mathrm{m}^{2}$. day (LI-Cor: LI-1000). Each condition was tested in triplicate using three adults for each aquarium. Seaweeds were harvested weekly from intertidal flats and maintained in the laboratory. Animals were fed a known amount of seaweed adlibitum at least twice daily. Uneaten remnants of Ulva were collected with a dip-net and egg masses were removed from the aquaria and weighed every day; handling lasted for about $50 \mathrm{~s}$ for each aquarium. The sea hares were weighed every 10 days, after being placed on a towel to re-
Table 1. Specific growth rate (SGR), food conversion efficiency (FCE) and gonado-somatic index (GSI) of the sea hare Aplysia dactylomela fed on green seaweed Ulva pertusa under a dark and natural light regime for a period of 30 days

\begin{tabular}{lcc}
\hline & \multicolumn{2}{c}{ Light regime } \\
\cline { 2 - 3 } Performance Indicators & $\begin{array}{c}\text { Dark } \\
(24 \mathrm{~h})\end{array}$ & $\begin{array}{c}\text { Natural photoperiod } \\
(11.2 \pm 0.3 \mathrm{~h} \text { Dark })\end{array}$ \\
\hline Body weight (dry, g/ind) & & \\
$\quad$ Initial & $19.8 \pm 0.6$ & $19.6 \pm 0.6$ \\
$\quad$ Final (after 30 days) & $39.7 \pm 1.7^{* *}$ & $28.7 \pm 1.9$ \\
SGR (\%/day) & $2.31 \pm 0.10^{* *}$ & $1.28+0.03$ \\
FCE (\%) & $15.4 \pm 1.0^{*}$ & $11.5 \pm 0.4$ \\
GSI & $0.10 \pm 0.02$ & $0.21 \pm 0.02^{* *}$ \\
\hline
\end{tabular}

The values are expressed as mean \pm S.D.

Differences were, ${ }^{*}$ significant at $p<0.05 ;{ }^{* *}$ significant at $p<0.01$.

move excess water. All handling was done at night under a dim light which was placed far from the aquaria. Time of exposure to the dim light and handling were minimized to reduce disturbance to the Aplysia during the dark period. Dry weight equivalents of body weights, egg masses and seaweed were obtained by correcting for moisture content. This was obtained by drying 12,21 and 9 separate samples of animals, egg masses and seaweeds respectively, at $110^{\circ} \mathrm{C}$ and averaging the results. Wet weight conversion factors were $0.093 \pm 0.005$ for body weight, $0.095 \pm 0.011$ for egg masses and $0.164 \pm 0.001$ for the Ulva. The experiment was run for 30 days (after which growth gain of the animals fed on the dark regime reached a value twice their initial body weight) and specific growth rate (SGR), food conversion efficiency (FCE) and gonado-somatic index (GSI) were calculated. Computations were as follows: $\mathrm{SGR}=100[\ln (w f / w i) /(t f-t i)] ; \quad \mathrm{FCE}=100[(w f-w i) / S] ;$ $\mathrm{GSI}=E / w f$, where $w f=$ final dry weight of the animal $(\mathrm{g})$, $w i=$ initial dry weight of the animal $(\mathrm{g}), t f=$ final time (day), $t i=$ initial time (day), $S=$ dry weight of seaweed consumed (g), $E=$ dry weight of the eggs produced (g). All the water was exchanged daily. Water temperature during the experiment ranged from 17 to $20^{\circ} \mathrm{C}$. Results are summarized in Table 1. The adults showed a greater increase in body weight under the dark regime, with higher SGR and FCE. On the other hand, adults under the natural light re- 
gime showed twice the GSI; possibly due to the conversion of energy from somatic growth to egg production. $A$. dactylomela is active nocturnally and inactive to varying extents during daylight hours. ${ }^{7,9)}$ Aplysia fed in the dark regime in our experiment ate constantly and had subsequently greater growth rates. The highest egg producers (high GSI) were animals that grew under natural photoperiodthe light regime. Previous studies have shown that hormones associated with egg-laying, inhibit feeding, ${ }^{10)}$ and this could be an additional limiting factor to the time spent by animals feeding under the natural photoperiod. Our results showed that the consumption of the algae, the body weight increase and egg production in $A$. dactylomela were significantly affected by the light regime, and that this environmental factor can be used for the management of algae or to either increase the weight of Aplysia or its egg production.

\section{References}

1) E. R. Kandel: Behavioral Biology of Aplysia: A Contribution to the
Comparative Study of Opisthobranch Molluscs, (ed. by W. H. Freeman, and Co.), San Francisco. 1979, p. 463.

2) F. J. Schmitz, K. H. Hollenbeak, D. C. Carter, M. B. Hossain, and D. van der Helm: J. org. Chem., 44, 2445-2447 (1979).

3) A. G. Gonzalez, J. D. Martin, M. Norte, R. Perez, and V. Weyler: Tetrah. Lett., 24, 1075-1076 (1983).

4) H. Vandermeulen and H. Gordin: J. Appl. Phycol., 2, 363-374 (1990).

5) J. Maze, P. Morand, and P. Potoky: J. Appl. Phycol., 5, 183-190 (1993).

6) K. Shigueno: Shrimp culture in Japan, Association for International Technical Promotion, Tokyo. 1975, p. 60.

7) T. H. Carefoot: J. Exp. Mar. Biol. Ecol., 5, 47-62 (1970).

8) Japan Meteorological Association, South Kyushu Center: in "Meteorological Tide Tables of Kagoshima Prefecture", Kawachi Press, Kagoshima, 1993, pp. 6-9 (in Japanese).

9) T. H. Carefoot: Proceedings of the Fifth International Coral Reef Congress. Tahiti, Vol. 4, 1985, pp. 9-16.

10) D. K. Stuart and F. Strumwasser: Journal of Neurophysiology, 48, 499-515 (1980). 